\title{
PENGEMBANGAN KOMPETENSI \\ KEWIRAUSAHAAN PELAKU UKM YANG TINGGAL DI PINGGIRAN ALIRAN SUNGAI PROGO YOGYAKARTA BERBASIS NILAI KARAKTER DAN KEARIFAN LOKAL
}

\author{
Wartomo \\ Universitas Terbuka, Yogjakarta \\ E-mail: wartomo@ut.ac.id
}

\begin{abstract}
Abstrak
Penelitian bertujuan mengungkap model pengembangan pelaku UKM (Usaha Kecil Menengah) berbasis nilai karakter dan kearifan lokal. Lebih spesifik tujuan penelitian ini, memahami kedudukan strategis nilai-nilai karakter dan keraifan lokal terhadap pengaruh ekonomi dalam membangun kehidupan sosial, ekonomi, dan pelaku UKM berbasis kearifan lokal. Subyek penelitian adalah pelaku UKM yang tinggal di pinggiran aliran Sungai Progo Yogyakarta yang masih melestarikan nilai karakter berbasis kearian lokal. Jenis penelitian Research and Development. Langkah-langkah penelitian diawali survey dan need assessment bagi masyarakat pelaku UKM, pembinaan nilai karakter lokal, media pelaksanaan model, aksi atau tindakan, dan evaluasi. Penelitian dilaksa-nakan di wilayah Kabupaten Kulonprogo Yogyakarta, khususnya di bantaran atau pinggiran aliran Sungai Progo Yogyakarta bagi kelompok UKM, dilaksanakan selama 6 (enam) bulan; yaitu bulan April-September 2015. Teknik pengumpulan data menggunakan observasi, interview, demonstrasi, dan simulasi. Analisis data menggunakan pendekatan kuantitatif dengan program LISREL (Linear Structural Relations). Hasil penelitian adalah: (1) diperoleh data dasar potensi desa di wilayah penelitian yang berkaitan dengan permasalahan dan penunjang pelaksanaan pengembangan jiwa dan kompetensi kewirausahaan bagi masyarakat miskin melalui nilai karakter dan kearifan lokal, (2) dapat diperoleh data dasar angka prevalensi jumlah masyarakat pelaku UKM; (3) dapat dilakukan need asessment dari masyarakat pelaku UKM pengembangan melalui nilai karakter dan kearifan lokal, yang berhasil dijaring dan terdidentifikasi, (4) dapat disusun model pengembangan jiwa dan kompetensi kewirausahaan bagi masyarakat kelompok UKM melalui nilai karakter; (5) dapat disusun tim instruktur dan pelaksana kegiatan program pengembangan jiwa dan kompetensi kewirausahaan bagi masyarakat pelaku UKM melalui nilai karakter; (6) memberikan peluang sejumlah kurang lebih 50 pelaku UKM untuk meningkatkan pengembangan jiwa dan kompetensi kewirausahaan melalui pembinaan nilai karakter dan kearifan lokal; (7) dapat meningkatkan pengembangan jiwa dan kompetensi kewirausahaan melalui pembinaan nilai karakter bagi masyarakat pelaku UKM; (8) menciptakan suasana berwirausaha melalui pembinaan nilai karakter bagi masyarakat pelaku UKM yang tinggal dibantaran atau pinggiran aliran Sungai Progo Yogyakarta; (9) dapat disusun artikel untuk ditulis dalam jurnal nasional maupun internasional, dan ditulis buku teks untuk kepentingan bahan kuliah mahasiswa.
\end{abstract}

Kata Kunci: Pengembangan Kewirausahaan; Pelaku UKM; Nilai Karakter dan Kearifan Lokal. 


\section{PENDAHULUAN}

Negara Kesatuan Republik Indonesia memiliki wilayah yang luas, kondisi geografis maupun sosiokultural sangat hiterogen, di beberapa wilayah kondisi ekonominya masih mengalami permasalahan, terutama daerah terpencil dan tertinggal; termasuk khususnya daerah perbukitan di bantaran pinggiran aliran Sungai Progo wilayah Kabupaten Kulonprogo Yogyakarta. Permasalahan yang muncul; kewajiban negara dalam bidang ekonomi adalah belum kecukupan ekonomi yang merata dan berkualitas bagi semua warga negara yang tinggal di pedesaan.

Berdasarkan latar belakang di atas, penelitian ini bertujuan untuk meneliti model pengembang masyarakat pelaku UKM dalam perspektif nilai karakter dan kearifan lokal. Lebih spesifik tujuan penelitian ini yaitu: memahami kedudukan strategis nilai-nilai karakter dan keraifan lokal terhadap pengaruh ekonomi dalam membangun kehidupan sosial, ekonomi, dan budaya lokal. Khususnya di wilayah Kabupaten Kulonprogo, pasca direalisasikannya rehabilitasi atau perbaikan Sungai Progo, diharapkan tidak hanya sekedar menjadi kebutuhan primer manusia semata, tetapi juga merupakan kebutuhan ekonomi. Keberadaan Sungai Progo harus dapat berdampak positif bagi pembangunan ekonomi wilayah Kabupaten Kulonprogo, termasuk bagi sektor UKM (Usaha Kecil Menengah). Hal ini cukup beralasan karena sektor UKM telah menjadi salah satu pilar penting dalam perekono-mian regional wilayah Kabupaten Kulonprogo dalam konteks industrialisasi.

Seyogyanya, gelombang industrialiasi yang akan terjadi di Kulonprogo harus dijadikan sebagai peluang strategis sekaligus tantangan positif untuk meningkatkan kualitas dan pemberdayaan diri melalui pembinaan nilai karakter, agar mampu memainkan peranan yang strategis di dalamnya. Akan tetapi, tentu saja industrialisi seperti diurakan Binsar A. Hutabarat (2010) menuntut adanya masyarakat yang mempunyai keunggulan kompetitif dengan SDM mumpuni, dan kekuatan investasi modal intelektual serta penguasaan masyarakat terhadap sarana informasi yang serba superhigh technology. Industrialisasi di wilayah Kulonprogo akan ditandai dengan maraknya kehidupan bisnis yang menjanjikan di masa depan dengan mengandalkan pembinaan nilai karakter, sehingga dituntut adanya kemampuan entrepreneurship yang baik. Untuk itu, masyarakat UKM di wilayah Kabupaten Kulonprogo harus menyadari kemampuannya untuk bersaing karena aktivitas dan pekerjaan dalam industrialisasi menuntut kecang-gihan ilmu pengetahuan dan teknologi serta keterampilan (skill) khusus yang didukung jiwa kewirausahaan yang baik. Hal ini hanya dapat diraih dengan pengembangan jiwa dan kompetensi kewirausahaan bagi masyarakat pelaku UKM melalui pembinaan nilai karakter berbasis kearifan lokal.

Untuk mendukung penyusunan artikel ini, sebelumnya penulis telah melakukan bergai kegiatan penelitian yang berkaitan dengan pengembangan jiwa dan kompetensi kewirausahaan bagi masyarakat pelaku UKM melalui pengembangan nilai karakter berbasis kearifan lokal. Penulis tertarik tema artikel yang berkaitan dengan membangun jiwa dan kompetensi kewirausahaan bagi masyarakat pelaku UKM melalui pembinaan nilai karakter berbasis kearifan lokal dengan alasan: (1) penulisan ini menindaklanjuti tulisan sebelumnya, (2) membantu masyarakat miskin dalam usaha pendekatan pendidikan karakter bangsa berbasis kearifan lokal bagi masyarakat pelaku UKM yang bertempat tinggal di wilayah bantaran atau pinggiran aliran Sungai Progo Yogyakarta.

Mencermati permasalahan di atas, tujuan penelitian adalah: (1) mengetahui ujicoba model pengembangan jiwa dan kompetensi kewirausahaan bagi masyarakat pelaku UKM yang tinggal di pinggiran sepanjang aliran waduk gajah mungkur melalui nilai karakter berbasis kearifan lokal; (2) penanaman dalam pelaksanaan pengembangan jiwa dan 
kompetensi kewirausahaan bagi masyarakat pelaku UKM yang tinggal di pinggiran sepanjang aliran Sungai Progo melalui nilai karakter berbasis kearifan lokal; (3) mengetahui efektivitas model pengembangan jiwa dan kompetensi kewirausahaan bagi masyarakat pelaku UKM yang tinrggal di pinggiran sepanjang aliran Sungai Progo melalui nilai karakter dan kearifan lokal; (4) pengembangan jiwa dan kompetensi kewirausahaan bagi masyarakat pelaku UKM yang tinggal di pinggiran sepanjang aliran Sungai Progo melalui nilai karakter dan kearifan lokal supaya menjadi UKM yang baik dan profesional, warga masyarakat dan warga negara yang memiliki budi pekerti luhur; (5) sebagai warga masyarakat akan terbentuk sifat karakter yang bertanggungjawab, disiplin, dan jujur dalam mengelola UKM dan lembaga di mana mereka berusaha atau bekerja.

\section{KAJIAN TEORI}

Istilah kewirausahaan dipahami sebagai proses mengerjakan sesuatu yang baru (creative), dan sesuatu yang berbeda (innovative) dan bermanfaat untuk memberikan nilai lebih. Beberapa konsep yang ada terdapat enam hakekat penting kewirausahaan Arif Budi Wurianto, (2006), yaitu: (1) kewirausahaan adalah nilai yang diwujudkan dalam perilaku yang dijadikan dasar sumber daya, tenaga penggerak, tujuan, siasat, kiat, proses dan hasil bisnis; (2) kewirausahaan adalah kemampuan menciptakan sesuatu yang baru dan berbeda (ability to create the new and different); (3) kewirausahaan adalah proses penerapan kreativitas dan keinovasian dalam memecahkan persoalan dan menemukan peluang untuk memperbaiki kehidupan usaha; (4) kewirausahaan adalah nilai yang diperlukan untuk memulai usaha (start up phase) dan perkembangan usaha (venture growth); (5) kewirausahaan adalah proses dalam mengerjakan sesuatu yang baru (creative), dan sesuatu yang berbeda (inovative) yang bermanfaat memberi nilai lebih; (6) kewirausahaan adalah usaha menciptakan nilai tambah dengan jalan mengkombinasikan sumber-sumber melalui cara-cara baru dan berbeda untuk memenangkan persaingan.

Pendapat Patel V.G., (2005) entrepreneurship (kewirausahaan) adalah proses menciptakan sesuatu yang baru dan berani mengambil risiko dan mendapatkan keuntungan. Para ahli sepakat bahwa yang dimaksud dengan kewirausahaan menyangkut tiga perilaku yaitu: (1) kreatif, (2) komitmen (motivasi tinggi dan penuh tanggung jawab), dan (3) berani mengambil risiko dan kegagalan. Kewirausahaan adalah proses inovasi dan kreasi. Orang yang berwirausaha disebut wirausahawan (entrepreneur). Entrepreneur adalah inovator dan kreator (Kao, 1991). Entrepreneur ialah seorang inovator (Hisrich \& Peters, 2002). Kewirausahaan adalah singkatan dari: Kreatif, Enerjik, Wawasan luas, Inovatif, Rencana bisnis, Agresif, Ulet, Supel, Antusias, Hemat, Asa, Antusias, Negosiatif. Buchari, (2006) istilah wirausaha berasal dari kata entrepreneur (bahasa Francis) yang diterjemahkan ke dalam bahasa Inggris dengan arti between taker atau go-between. Pendapat Suparman Sumohamijaya (1980) istilah wirausaha sama dengan istilah wiraswasta. Wiraswasta berarti keberanian, keutamaan dan keperkasaan dalam memenuhi kebutuhan serta memecahkan permasalahan hidup dengan kekuatan yang ada pada diri sendiri.

Tarsis Tarmiji (1987) mengmukakan, seorang wirusaha dapat dideskripsikan sebagai seorang yang mempunyai dan memakai atribut: (1) wawasan komersial dan kesadaran akan pasar, (2) kemampuan untuk bekerja secara tekun dan mandiri, (3) pikiran yang inovatif dan kreatif, (4) kemampuan untuk menejemeni dan menggarahkan perubahan, (5) kapasitas mengorganisasi dan keterampilan analitik, (6) stamina dan daya tahan, (7) kemampuan untuk bergaul yang baik dengan orang dari segala tingkatan. 
Membangun jiwa KWU dalam kontek karakter; pengertian karakter menurut Pusat Bahasa Depdiknas adalah bawaan, hati, jiwa, kepribadian, budi pekerti, perilaku, personalitas, sifat, tabiat, temperamen, watak. Adapun berkarakter adalah berkepribadian, berperilaku, bersifat, bertabiat, dan berwatak. Ki Tyasno Sudarto (2007), karakter mengacu kepada serangkaian sikap (attitudes), perilaku (behaviors), motivasi (motivations), dan keterampilan (skills). Karakter berasal dari bahasa Yunani yang berarti "to mark" atau menandai dan memfokuskan bagaimana mengaplikasikan nilai kebaikan dalam bentuk tindakan atau tingkah laku, sehingga orang yang tidak jujur, kejam, rakus dan perilaku jelek lainnya dikatakan orang berkarakter jelek. Sebaliknya, orang yang perilakunya sesuai dengan kaidah moral disebut dengan berkarakter mulia.

Magnis Suseno Frans (1987) karakter mulia berarti individu memiliki pengetahuan tentang potensi dirinya, yang ditandai dengan nilai-nilai seperti reflektif, percaya diri, rasional, logis, kritis, analitis, kreatif dan inovatif, mandiri, hidup sehat, bertanggung jawab, cinta ilmu, sabar, berhati-hati, rela berkorban, pemberani, dapat dipercaya, jujur, menepati janji, adil, rendah hati, malu berbuat salah, pemaaf, berhati lembut, setia, bekerja keras, tekun, ulet/gigih, teliti, berinisiatif, berpikir positif, disiplin, antisipatif, inisiatif, visioner, bersahaja, bersema-ngat, dinamis, hemat/efisien, menghargai waktu, pengabdia/dedikatif, pengendalian diri, produktif, ramah, cinta keindahan (estetis), sportif, tabah, terbuka, tertib. Individu juga memiliki kesadaran untuk berbuat yang terbaik atau unggul, dan individu juga mampu bertindak sesuai potensi dan kesadarannya tersebut. Karakteristik adalah realisasi perkembangan positif sebagai individu (intelektual, emosional, sosial, etika, dan perilaku).

Ropke (1989), pendidikan karakter dimaknai sebagai berikut: character educa-tion is the deliberate effort to help people understand, care about, and act upon core ethical values. When we think about the kind of character we want for our children, it is clear that we want them to be able to judge what is right, care deeply about what is right, and then do what they believe to be right, even in the face of pressure from without and temptation from within. Lebih lanjut dijelaskan bahwa pendidikan karakter adalah segala sesuatu yang dilakukan guru, yang mampu mempengaruhi karakter peserta didik. Guru membantu membentuk watak peserta didik. Hal ini mencakup keteladanan bagaimana perilaku guru, cara guru berbicara atau menyampaikan materi, bagaimana guru bertoleransi, dan berbagai hal terkait lainnya.

Maksum (2004) pendidikan karakter memiliki esensi dan makna yang sama dengan pendidikan moral dan pendidikan akhlak. Tujuannya adalah memben-tuk pribadi anak, supaya menjadi manusia yang baik, warga masyarakat, dan warga negara yang baik. Adapun kriteria manusia yang baik, warga masyarakat yang baik, dan warga negara yang baik bagi suatu masyarakat atau bangsa, secara umum adalah nilai-nilai sosial tertentu, yang banyak dipengaruhi oleh budaya masyarakat dan bangsanya. Oleh karena itu, hakikat dari pendidikan karakter dalam konteks pendidikan di Indonesia adalah pedidikan nilai, yakni pendidikan nilai luhur yang bersumber dari budaya bangsa Indonesia sendiri, dalam rangka membina kepribadian generasi muda.

Berdasarkan grand design yang dikembangkan Kemendiknas (2010), secara psikologis dan sosial kultural pembentukan karakter dalam diri individu merupakan fungsi dari seluruh potensi individu manusia (kognitif, afektif, konatif, dan psikomotorik) dalam konteks interaksi sosial kultural (dalam keluarga, sekolah, dan masyarakat) dan berlangsung sepanjang hayat. Bill Drayton (2007) konfigurasi karakter dalam konteks totalitas proses psikologis dan sosial-kultural tersebut dapat dikelompokkan dalam: olah hati (spiritual and emotional development), olah pikir (intellectual development), olah raga dan kinestetik (Physical and kinestetic development), dan olah rasa dan karsa (Affective and Creativity development).

Arismunandar, (2006) lebih panjang merumuskan tentang karakter sebagai konsepsi 
dari apa yang diinginkan, yang memengaruhi pilihan terhadap cara, tujuan antara dan tujuan akhir tindakan. Maksum (2004) mengungkapkan bahwa definisi nilai karakter memiliki banyak implikasi terhadap pemaknaan nilai-nilai budaya, dalam pengertian lebih spesifik implikasi yang dimaksud adalah: (1) nilai karakter merupakan konstruk yang melibatkan proses kognitif (logis dan rasional) dan proses katektik (ketertarikan atau penolakan menurut kata hati); (2) nilai krakter selalu berfungsi secara potensial, tetapi selalu tidak bermakna apabila diverbalisasi; (3) apabila hal itu berkenan dengan budaya, nilai karakter diungkapkan dengan cara yang unik oleh individu atau kelompok.

Kaitannya dengan nilai karakter diartikan sebagai (1) kualitas dan kuantitas reaksi terhadap diri sendiri, orang lain, maupun situasi terntentu; (2) watak, akhlak, ciri psikologis. Magnis Suseno Frans (1987), ciri-ciri psikologis yang dimiliki pelaku wirausaha pada lingkup pribadi, secara evolutif akan berkembang menjadi ciri kelompok dan lebih luas lagi menjadi ciri sosial. Ciri psikologis individu akan memberi warna dan corak identitas kelompok dan pada tatanan makro akan menjadi ciri psikologis atau karakter suatu pelaku kewirausahaan. Pembentukan karakter suatu bangsa berproses secara dinamis sebagai suatu fenomena sosio-ekologis.

Sebagai identitas atau jati diri suatu bangsa, karakter merupakan nilai dasar perilaku yang menjadi acuan tata nilai interaksi antar manusia (when character is lost then every ting is lost). Bygrave (2004) secara universal berbagai karakter dirumuskan sebagai nilai hidup bersama berdasarkan pilar: kedamaian (peace), menghargai (respect), kerjasama (cooperation), kebebasan (fredom), kebahagiaan (happinnes), kejujuran (honesty), kerendahan hati (humility), kasih sayang (love), tanggung jawab (responsibility), kesederhanaan (simplicty), toleransi (tolerance) dan peratuan (unity). Filosofis karakter dikemukakan oleh Ketua Umum Majelis Hukum Taman Siswo Ki Tyasno Sudarto (2007) yaitu: (1) mahayu hayuning saliro (bagaimana hidup untuk meningkatkan kualitas diri); (2) mahayu hayuning bongso (bagaimana berjuang untuk negara dan bangsa); (3) mahayu hayuning bawana (bagaimana membangun kesejahteraan dunia).

Sebagai pelaku kewirausahaan, untuk mencapai tatanan Tri Rahayu tersebut, manusia harus memahami, menghayati, serta melaksanakan tugasnya sebagai manusia yang tercantum dalam Tri Satya Brata: (1) rahayuning bawono kapurbo waksitaning manungso (kesejahteraan dunia tergantung pada manusia yang memiliki ketajaman rasa); (2) dharmaning manungso mahanani rahayuning negara (tugas utama dalam menjaga keselamatan negara); (3) rahayuning manungso dumadi karana kemanungsane (keselamatan manusia ditentukan tata perilakunya). Nilai-nilai karakter pendekatan akademis yang dimaksudkan adalah iman, taqwa, berakhlak mulia, berilmu, jujur, disiplin, demokratis, adil, bertanggung jawab, orientasi pada keunggulan, gotong royong, dan lain sebagainya. Benang merah dalam penelitian ini adalah bagaimana membangun kewirausahaan lokal di wilayah Kulonprogo. Intinya bagaimana potensi kewirausahaan bisa dikembangkan sesuai dengan jati diri masyarakat dan budaya Kulonprogo, sehingga mampu berdaya saing global. Wartomo, (2011) cita-cita besar ini bisa dicapai apabila ada empat (4) unsur yang bekerja sinergis dan saling mengisi. Keempat unsur syarat itu ialah pemerintah yang bersih dan berwibawa, banyak ilmuwan pendidik profesional atau intelektual yang rela melakukan penelitian yang hasilnya dipersembahkan bagi masyarakat, terdapat wirausahawan dalam jumlah banyak, serta masyarakat yang berbudaya disiplin dan berkinerja baik. 
Dalam hal kearifan lokal Puja Raharja, (2006) mengemukakan, kebijaksanaan hidup yang didasarkan pada nilai-nilai kebudayaan suatu masyarakat. Kearifan lokal merepresentasikan sebuah nilai kebudayaan masyarakat yang menaungi keseluruhan kompleksitas norma dan perilaku yang dijunjung tinggi serta menjadi sebuah "belief". Kearifan lokal dalam kenyataan sehari-hari dapat ditemui dalam nyayian, pepatah, sasanti, petuah, semboyan, kesusasteraan, dan naskah-naskah kuno yang melekat dalam perilaku sehari-hari. Unsur revitalisasi kearifan lokal dalam merespon lingkungan adalah melalui penguatan masyarakat berbasis inisiatif-inisiatif lokal. Ciri dasar kearifan lokal adalah adanya kepedulian sesama manusia dan alam semesta.

Kearifan lokal perlu diintegrasikan dalam gerakan sosial dan kebudayaan masyarakat. Dengan gerakan semacam ini, akan mampu membawa kesadaran dalam hati nurani masyarakat luas dalam menghadapi persoalan perspektif pendidikan, Wartomo, (2011) upaya pengembangan pemberdayaan potensi lokal yang dilakukan antara lain (a) pengembangan sumberdaya kelembagaan budaya dan pendidikan melalui optimalisasi dan peningkatan kemampuan pendidikan dan latihan pengenalan karakter berbasis kearifan lokal, (b) pengembangan sumberdaya kelembagaan budaya dan pendidikan lewat pengadaan program pendidikan dan latihan pengendalian dan pengelolaan pendidikan karakter berbasis kearifan lokal/inisiatif-inisiatif lokal. (c) secara akademis perlu pengembangan tenaga perancang dan peneliti dalam berbagai bidang yang secara lintas disiplin mampu menyelesaikan persoalan pendidikan karakter dengan pendekatan yang berbasis kearifan lokal/inisiatif-inisiatif lokal.

Arif Budi Wurianto (2005) model nilai karakter berbasis kearifan lokal adalah model yang memiliki relevansi tinggi bagi pengembangan kecakapan hidup (life skills) dengan bertumpu pada pemberdayaan keterampilan dan potensi kebudayaan lokal di masing-masing daerah. Dalam model pendidikan ini, materi pembelajaran memiliki makna dan relevansi tinggi terhadap pemberdayaan hidup UKM secara nyata, berdasarkan realitas yang dihadapi. Berkaitan model pengembangan kompetensi kewirausahaan bagi masyarakat pelaku UKM berbasis nilai karakter dan kearifan lokal; mengutip pendapat Power, F.C., (2004), terdapat 9 (sembilan) pilar karakter tersebut adalah: (1) cinta tuhan dan segenap ciptaanNya (love Allah, trust, reverence, loyalty); (2) tanggung jawab, kedisiplinan dan kemandirian (responsibility, excellence, self reliance, discipline, orderliness); (3) kejujuran/amanah dan arif (trustworthines, honesty, and tactful); (4) hormat dan santun (respect, courtesy, obedience); (5) dermawan, suka menolong dan gotong-royong/kerjasama (love, compassion, caring, empathy, generousity, moderation, cooperation) ; (6) percaya diri, kreatif dan pekerja keras (confidence, assertiveness, creativity, resourcefulness, courage, determination, enthusiasm); (7) kepemimpinan dan keadilan (justice, fairness, mercy, leadership); (8) baik dan rendah hati (kindness, friendliness, humility, modesty); (9) toleransi, kedamaian dan kesatuan (tolerance, flexibility, peacefulness, unity).

Filosofis nilai karakter dikemukakan oleh Ketua Umum Majelis Hukum Taman Siswo Ki Tyasno Sudarto (2007) yaitu: (1) mahayu hayuning saliro (bagaimana hidup untuk meningkatkan kualitas diri); (2) mahayu hayuning bongso (bagaimana berjuang untuk negara dan bangsa); (3) mahayu hayuning bawana (bagaimana membangun kesejahteraan dunia). Dalam upaya untuk mengaktualisasikan nilai karakter, dituntut peran penting dari pimpinan dan jajaran perguruan tinggi dalam program peningkatan kapasitas, khususnya perannya sebagai: (1) character builders, yaitu membangun kembali karakter positif para akademisi dengan menjunjung nilai-nilai moral di atas kepentingan sesaat dan 
menginternalisasikan pada kegiatan dan aktifitasnya sehari-hari; (2) character enabler, yaitu pemberdayaan secara terus menerus karakter akademisi dengan bersedia menjadi role model dari pengembangan karakter di lingkungannya; dan (3) character enginer, yaitu terus menerus melakukan pembelajaran pengembangan karakter yang menuntut adanya modifikasi dan rekayasa yang tepat disesuaikan dengan perkembangan jaman.

Penelitian Wartomo (2011) perhatian dan upaya untuk mengembangkan kewirausahaan telah banyak dilakukan pemerintah, swasta dan pihak perbankan. Hal tersebut ditandai dengan meningkatnya perhatian tiga pihak tersebut dengan mena-warkan banyak program terkait kewirausahaan. Agenda membangun jiwa dan kompetensi kewirausahaan yang dilakukan, meliputi aspek: pendidikan, regulasi, sumber daya manusia, permodalan, pembiayaan, dan lainnya.

\section{METODE PENELITIAN}

Penelitian menguji model pengembangan kompetensi kewirausahaan bagi pelaku UKM yang tinggal di bantaran aliran Sungai Progo Yogyakarta berbasis nilai karakter dan kearifan lokal. Menggunakan siklus tahapan pengembangan R\&D dari Borg and Gall (1989). Model ini diuji secara teoritik maupun secara empirik di lapangan setelah ditemukan model secara tentatif melalui penelitian pendahuluan. Desain Research and Development $(R \& D)$ Borg \& Gall memberikan rujukan kepada peneliti bahwa untuk melakukan penelitian dan pengembangan, ditetapkan sepuluh langkah utama.

Variabel yang dilibatkan dalam penelitian ini meliputi: (1) jiwa dan kompetensi kewirausahaan, (2) pilar nilai karakter lokal. Mengacu tiga variabel pengem-bangan dan kompetensi kewirausahaan bagi Sungai Progo Yogyakarta masyarakat miskin yang tinggal dibantaran atau pinggiran saluran melalui pengembangan nilai karakter lokal, yaitu melestarikan kearifan lokal, dapat disusun suatu model hipotetik yang memposisikan intensitas pelayanan model; terdiri dari subvariabel: (1) kompetensi kewirausahaan; terdiri dari sub variabel: (a) percaya diri dan berinisiatif; (b) motif berusaha; (c) jiwa berwirausaha; (d) mengetahui usaha apa yang akan dilakukan; (e) kemampuan mengelola keuangan; (f) kemampuan mengatur waktu; (g) kemampuan merencanakan; (h)memberi kepuasan kepada pelanggan; (i) mengetahui strategi/cara bersaing; (2) pilar nilai karakter; terdiri dari sub variabel: (a) kedamaian; (b) menghargai; (c) kerjasama; (e) kejujuran; (f) kerendahan hati; (g) kasih sayang (h) tanggung jawab; (i) kesederhanaan; (j) toleransi

Subyek penelitian: (1) masyarakat miskin pelaku UKM tinggal dibantaran atau pinggiran aliran Sungai Prrogo melalui pengembangan nilai karakter lokal; (2) aparatur pemerintah (Dinas Koperasi, Dinas Perindustrian dan Perdagangan, KADIN) yang terkait dengan pelaku UKM; di wilayah Kabupaten Kulonprogo; (3) lembaga perguruan tinggi, berbagai lembaga swadaya masyarakat, asosiasi yang menangani pelaku UKM.

Penelitian dilaksanakan di wilayah Kabupaten Kulonprogo khususnya bantaran atau pinggiran aliran Sungai Progo Yogyakarta di desa Tuksono, Kecamatan Sentolo. Dipilihnya wilayah ini berdasarkan studi pendahuluan banyak ditemukan masyarakat pelaku UKM bermasalah yang masih melestarikan nilai karakter dan kearifan lokal yang perlu pembinaan. Penelitia dilaksanakan selama 6 (enam) bulan, dimulai bulan April bulan Oktober 2015.

Jenis data dan metode yang digunakan: (1) data penjaringan, identifikasi, dan need assessment masyarakat miskin pelaku UKM tinggal dibantaran pinggiran saluran waduk gajah mungkur melalui nilai karakter lokal dengan cara survey, observasi, dan interview; 
(2) data materi simulasi untuk instruktur model disusun dengan cara lokakarya dengan Dinas Pemerintah terkait, tim ahli, tokoh masyarakat, dan peneliti; (3) data tentang kemampuan instruktur pelaksana model dikumpulkan dengan angket, intiversie, dan observasi; (4) data tentang rancangan pelaksanaan operasional model, diperoleh melalui wawancara dan observasi; (5) data tentang efektifitas penerapan pengembangan jiwa dan kompetensi kewira-usahaan bagi masyarakat miskin tinggal dibantaran atau pinggiran aliran Sungai Progo melalui pengembangan nilai karakter lokal; akan dikumpulkan dengan menggunakan metode angket, tes, observasi, dan interview. Data yang telah dikumpulkan diedit, dan selanjut diproses melalui komputer. Analisis data menggunakan teknik terpadu antara pendekatan kuantitatif dengan program LISREL (Linear Structural Relations), dan kualitatif dengan model interaktif.

\section{HASIL PENELITIAN}

Berkaitan dengan model pengembanan kompetensi kewirausahaan bagi pelaku UKM yang tinggal di bantaran aliran Sungai Progo Yogyakarta berbasis nilai karakter dan kearifan lokal; beberapa penelitian yang telah dilakukan adalah: (1) pentingnya pendidikan dan sosialisasi nilai moral dalam mewujudkan masyarakat sipil memiliki nilai karakter dan moral; (2) model pendidikan anti korupsi bagi mahasiswa di Perguruan Tinggi dalam mewujudkan warga negara yang baik; (3) pentingnya pendidikan multikultural dalam masyarakat majemuk; (4) hubungan orientasi nilai budaya dan pendidikan bagi penduduk tertinggal. Penelitian tersebut dilakukan membantu masyarakat miskin dalam usaha berwwirausaha yang mempertimbangkan nilai karakter. Untuk merancang pengembangan jiwa dan kompetensi kewirausahaan bagi masyarakat miskin melalui nilai karakter yang ditawarkan, banyak ditemukan hasil penelitian yang dapat mendukung konsep model. Benang merah dalam penelitian ini adalah bagaimana membangun kewirausahaan lokal di wilayah Kulonprogo. Intinya bagaimana potensi kewirausahaan bisa dikembangkan sesuai dengan jati diri masyarakat dan budaya Kulonprogo, sehingga para UKM yang tergolong miskin mampu berdaya saing global. Cita-cita besar ini bisa dicapai apabila ada empat (4) unsur yang bekerja sinergis dan saling mengisi.

Keempat unsur syarat itu ialah pemerintah yang bersih dan berwibawa, banyak ilmuwan pendidik profesional atau intelektual yang rela melakukan penelitian yang hasilnya dipersembahkan bagi masyarakat, terdapat wirausahawan dalam jumlah banyak, serta masyarakat yang berbudaya disiplin dan berkinerja baik.

Membangun jiwa dan kompetensi masyarakat berwawasan kewirausahaan lokal Kulonprogo memang tidaklah mudah, lebih mudah dipikirkan dan diucapkan daripada melaksanakannya. Setidaknya, hal tersebut tercermin dari adanya kendala dalam membangun budaya kewirausahaan. Prinsip-prinsip dalam kewirausahaan adalah bagaimana membangun karakteristik yang tangguh, kreatif, inovatif, cerdas, mandiri, dan mampu memanfaatkan peluang yang ada. Karena itu, pengembangan budaya kewirausahaan harus lintas bidang dan tidak sekedar berpikir bisnis.

Penelitian Wartomo (2011) perhatian dan upaya untuk mengembangkan kewirausahaan telah banyak dilakukan pemerintah, swasta dan pihak perbankan. Hal tersebut ditandai dengan meningkatnya perhatian tiga pihak tersebut dengan menawarkan banyak program terkait kewirausahaan. Agenda membangun kewira- 
usahaan yang dilakukan, meliputi aspek: pendidikan, regulasi, sumber daya manusia, permodalan, pembiayaan, dan lainnya. Target akhirnya adalah pencapaian kesuksesan kehidupan dunia akhirat, yang jawani disesuaikan dengan nilai jati diri dan budaya masyarakat Kulonprogo. Langkah-langkah pengembangan meliputi beberapa tahap sebagai berikut: (1) pengumpulan informasi; (2) perencanaan; (3) mengembangkan bentuk produk pendahuluan; (4) pengujian lapangan pendahuluan; (5) revisi produk utama; (6) pengujian lapangan utama; (7) revisi produk operasional; (8) pengujian lapangan operasional; (9) revisi produk akhir; (10) penyebaran dan implementasi.

Luaran penelitian sesuai dengan durasi yang diajukan: (1) diperoleh data dasar potensi kampung di wilayah penelitian yang berkaitan dengan permasalahan dan penunjang pelaksanaan pengembangan jiwa dan kompetensi kewirausahaan bagi masyarakat miskin melalui pengembangan nilai karakter lokal; (2) diperoleh data dasar angka prevalensi jumlah masyarakat miskin melalui pengembangan nilai karakter lokal; (3) dapat dilakukan need asessment dari pelaku pengembangan jiwa dan kompetensi kewirausahaan bagi masyarakat miskin melalui pengembangan nilai karakter lokal, yang berhasil dijaring dan terdidentifikasi; (4) disusun model pengembangan jiwa dan kompetensi kewirausahaan bagi masyarakat miskin melalui pengembangan nilai karakter lokal; (5) disusun modul, dan atikel untuk dapat dimasukkan atau ditulis dalam jurnal nasional maupun internasional; (6) disusun tim instruktur dan pelaksana kegiatan program pengembangan jiwa dan kompetensi kewirausahaan bagi masyarakat miskin melalui pengembangan nilai karakter dan budaya lokal; (7) adanya peningkatan pengembangan jiwa dan kompetensi kewirausahaan bagi masyarakat miskin melalui pengembangan nilai karakter lokal; (8) memberikan peluang sejumlah kurang lebih 50 UKM untuk meningkatkan pengembangan jiwa dan kompetensi kewirausahaan bagi masyarakat miskin melalui pengembangan nilai karakter lokal; (9) mendorong masyarakat UKM melalui pengembangan nilai karakter lokal; (11) disusun atikel untuk dimasukkan atau ditulis dalam jurnal nasional maupun internasional.

\section{KESIMPULAN}

Pengujian model pengembangan kompetensi kewirausahaan bagi pelaku UKM yang tinggal di bantaran aliran Sungai Progo Yogyakarta berbasis nilai karakter dan kearifan lokal; beberapa potensi UKM yang idealnya dapat digali dalam rangka menghadapi persaingan adalah: (a) kegiatan usaha UKM yang bersifat padat karya, sehingga tidak banyak memerlukan modal sebaliknya mampu menampung potensi sumberdaya manusia; (b) tidak memerlukan teknologi tinggi sehingga berpeluang untuk dilaksanakan oleh kalangan yang berpengetahuan terbatas; (c) banyak memanfaatkan sumberdaya lokal sehingga tidak banyak terpengaruh oleh gejolak perekonomian internasional, sebaliknya dapat merangsang pertumbuhan usaha lokal yang berdampak luas pada optimalisasi pemanfaatan seperti lahan, hasil-hasil pertanian tambang dan bahan galian, produk sampingan hasil hutan dan lain sebagainya. Dengan demikian ketergantungannya pada produk-produk barang import relatif rendah; (d) selang waktu produksi relatif singkat sehingga cepat menghasilkan produk dan; (e) produk barang bervariasi dari bahan mentah sampai dengan produk akhir; (f) mendorong masyarakat UKM melalui pengembangan nilai karakter lokal. Sebagian produk UKM 
merupakan bahan-bahan kebutuhan primer sedangkan sebagian lainnya merupakan barangbarang yang potensi pemasarannya baik di dalam maupun di luar negeri masih cukup luas.

Hasil penelitian dapat disimpulkan: (1) diperoleh data dasar potensi desa di wilayah penelitian yang berkaitan dengan permasalahan dan penunjang pelaksanaan pengembangan jiwa dan kompetensi kewirausahaan bagi masyarakat miskin melalui nilai karakter dan kearifan lokal, (2) dapat diperoleh data dasar angka prevalensi jumlah masyarakat pelaku UKM; (3) dapat dilakukan need asessment dari masyarakat pelaku UKM pengembangan melalui nilai karakter dan kearifan lokal, yang berhasil dijaring dan terdidentifikasi, (4) dapat disusun model pengembangan jiwa dan kompetensi kewirausahaan bagi masyarakat kelompok UKM melalui nilai karakter; (5) dapat disusun tim instruktur dan pelaksana kegiatan program pengembangan jiwa dan kompetensi kewirausahaan bagi masyarakat pelaku UKM melalui nilai karakter; (6) memberikan peluang sejumlah kurang lebih 50 masyarakat pelaku UKM untuk meningkatkan pengembangan jiwa dan kompetensi kewirausahaan melalui pembinaan nilai karakter dan kearifan lokal; (7) dapat meningkatkan pengembangan jiwa dan kompetensi kewirausahaan melalui pembinaan nilai karakter bagi masyarakat pelaku UKM; (8) menciptakan suasana berwirausaha melalui pembinaan nilai karakter bagi masyarakat pelaku UKM yang tinggal dibantaran atau pinggiran aliran aliran Sungai Progo Yogyakarta; (9) dapat disusun atikel untuk ditulis dalam jurnal nasional maupun internasional, dan ditulis buku teks untuk kepentingan bahan kuliah mahasiswa.

\section{DAFTAR PUSTAKA}

Arif Budi Wurianto, (2006), Jurnal Transformasi Nilai -Nilai Luhur Sastra Jawa Klasik Sebagai Pengembang "Content" Pendididikan Karakter Berkearifan Lokal di Sekolah, Yogyakarta.

Arismunandar. (2006). Pengembangan Kewirausahaan Sekolah, Direktorat Tenaga Kependidikan Departemen Pendidikan Nasional, Jakarta.

Buchari, (2006). Kewirausahaan Sekolah Berbasis Kreativitas dan Inovasi, Direktorat Tenaga Kependidikan Departemen Pendidikan Nasional, Jakarta.

Binsar A. Hutabarat. (2010). Karakter bangsa, dulu dan kini, dari file:/G/ karakter_bangsa_dulu_dan_kini.html. diunduh 27 April 2010.

Bill Drayton, Hanlon, D. and King, W. (2007), Some research perspectives on entrepreneurship education, enterprise education and education for small business management: a ten-year literature review, International Small Business Journal, Vol. 15 No. 3, pp. 56-77.

Borg R Walter, Gall Mredith D, (1989), Educational research, an intruduction, Routledge, New York.

Bygrave, William D. (2004). The Portable MBA in Entrepr-eneurship, John Willey \& Sons, Inc., New York.

Departemen Pendidikan Nasional. (2013). Panduan Pelaksanaan Hibah Penelitian dan Pengabdian Kepada Masyarakat: Jakarta. DP2M Dirjen Pendidikan Tinggi. 
Farhan Ahcmad. (2009). Metamorfosis Kehidupan Usaha Mikro Kecil dan Mengah yang tidak berjalan mulus. Harian Republika tanggal 23 Maret tahun 2006.

Kemendipdiknas. (2010). Kewirausahaan Sekolah. materi diklat pembinaan:komptetensi calon kepala sekolah/kepala sekolah). Jakarta.

Hisrich \& Peters (2003), It's not an exact science: teaching entrepreneurship in Northern Ireland, Journal of Education \& Training, 48(5), pp. 322-335, Emerald Group Publishing.

Imam Ghazali, Fuad, (2005). Structural equation modeling teori, konsep, dan aplikasi dengan program LISREL 8.54, Semarang: Badan Penerbit Universitas Diponegoro.

Ki Tyasno Sudarto. (2007). "Pengembangan nilai-nilai luhur budi pekerti sebagai karakter bangsa" dari file/H./Pengembangan\%20Nilai-nilai\% 20Luhur\% 20 Budi\% Pekerti. Diakses tanggal 12 Maret 2010.

Kantor Menteri Negara Urusan Koperasi dan Usaha Kecil dan Menengah Republik Indonesia (2006). Rencana strategi pembangunan koperasi, pengusaha kecil dan menengah

Kao, John, (1989), Entrepreneurship, Creativity \& Organization, Harvad Business School, Prentice Hall, Englewood, New Jersey.

Maksum dan Luluk YR. (2004). Paradigma pendidikan universal di era modern dan post modern, Yogyakarta: Penerbit Sarasin.

Magnis Suseno Frans. (1987). Etika dasar; masalah-masalah pokok filsafat moral, Jakarta: Penerbit Kanisius.

Menegkop dan UKM (2007). Pemberdayaan bisnis KUKM di bidang pemasaran dan jaringan usaha tahun 2006, Jakarta: Menegkop dan UKM.

Patel, V. G., (2005), Entrepreneurship Development Programme in India and Its Relevance Developing Countries, Entrepre-neurship Development Institute of India, Ahmedabad, in Louck: Training Entrepreneurs for Small Business Creation.

Power, F.C. (2004). Moral development. Ramachandran, V.C. (pnyt.). Encyclopedia of human behavior: 203-212. San Diego: Academic Press.

Puja Raharja,dkk. (2005), Kebudayaan Jawa Perpaduan Dengan Islam (Ikatan Penerbit Indonesia : Yogyakarta.

Ropke, (2009), Introduction: The Study of Business Entrepre-neurship in Comparative Perspective in: TT. Auang (ed); Burnese entrepreneurship Creative Response in the Colonial Economy, Wiesbaden, Franz Steiner Verdagg, pp vi-xvi.

Sugiyono, (2006), Metode penelitian pendidikan (Pendekatan kuantitatif dan kualitatif dan $R$ $\& D$., Penerbit Alfabeta Bandung.

Suparman Sumohamijaya (1980). Kewirausahaan yang berproses. Jakarta: PT. Gramedia Widiasarana Indonesia.

Tarsis Tarmudji. (1987). Pengantar Kewirausahaan. Bandung: Sinar Baru. 
Wartomo (2011). Model pengembangan pengusaha kecil menengah dalam usaha meningkatkan perekonomian daerah dan percepatan penanggulangan kemiskinan di perkotaan: UT BJJ Yogyakarta.

(2012). Pendekatan dan strategi pembangunan ekonomi yang berorientasi pada perbaikan iklim usaha kecil menengah di Kota Kulonprogo. (Bapeda Kulonprogo). UT BJJ Yogyakarta. 